\title{
Sons e Espacialidade, os Caminhos nos Cantos e Danças Guarani
}

\author{
Deise Lucy Oliveira Montardo
}

Universidade Federal do Amazonas, Manaus, Amazonas, Brasil

E-mail:deiselucy@gmail.com 


\section{Resumo}

Neste artigo faço uma reflexão sobre a importância das transcrições nos estudos de música e de dança indígenas, realçando os percursos interpretativos que me levaram à compreensão de que nos rituais guarani são percorridos caminhos que levam os participantes ao encontro dos heróis criadores e a outros seres espirituais. Defendo o esforço dedicado a criar ferramentas teórico-metodológicas para realizar transcrições que auxiliem a escuta e a observação dos rituais em movimentos que, dialogicamente, ajudem no entendimento desses universos.

Palavras-chave: Etnomusicologia. Antropologia da Música. Guarani. Kaiowá. Antropologia da Dança.

\section{Abstract}

In this article I reflect on the importance of transcriptions in studies of indigenous music and dance, highlighting the interpretative trajectories that led me to understand that participants in Guarani rituals take paths that lead them to encounter creative heroes and other spiritual beings. I support the creation of theoretical-methodological tools to carry out transcriptions that help in listening and observing rituals, in movements that, dialogically, help understand these universes.

Keywords: Ethnomusicology. Anthropology of Music. Guarani. Kaiowá. Anthropology of Dance. 


\section{Introdução}

S cantos e danças constituem caminhos que permitem aos Guarani o encontro com os seres espirituais, com seus heróis criadores e visitas a aldeias divinas. Ao percorrem os caminhos nos rituais, são executadas danças de lutas, com movimentos de ataque e defesa, os quais são preparação para enfrentar e desviar-se dos perigos do dia a dia. Cheguei a tal compreensão, baseada nas exegeses elaboradas junto aos meus interlocutores de pesquisa, e também na literatura sobre o grupo.

A interpretação dos cantos e danças guarani como caminhos foi feita baseada no que meus interlocutores Kaiowá e Nhandeva (da região conhecida hoje como sul do Mato Grosso do Sul-MS), ensinaramme acerca do que acontece nos rituais cotidianos, e que aparece nos desenhos feitos por Silvano Flores, nos quais os caminhos ficam evidentes, e também a partir da minha observação das coreografias e dos movimentos das danças.

A música como caminho aparece em outros grupos, tanto nas terras baixas da América do Sul, por exemplo, entre os Yaminaua, segundo Townsley (1993) e os Marubo, segundo Cesarino (2011); quanto em outras partes do planeta, como na Nova Guiné, como nos relata Feld (2012), entre os Kaluli e Roseman (1993) entre os Temiar. A relação da música com os caminhos e a espacialidade também aparece nos trabalhos feitos entre os aborígenes na Austrália, onde os cantos são mapas do território (Glowczewski, 1989).

No Alto Xingu, Seeger (1980) escreve sobre os cantos Kĩsêdjê que são gritados pelos irmãos para vencer a distância que estes vivem em relação as suas irmãs, das quais se separam quando têm cerca de 
oito anos de idade. No trabalho de Turino (1993) sobre os migrantes andinos em Lima, vemos um exemplo da criação de um ambiente, de um espaço, através das práticas musicais, que os tira do silêncio e os faz, de algum modo, se sentir no espaço andino, de onde vieram. Poderia elencar outros exemplos da associação entre música e espacialidade, mas vou retornar ao percurso da minha pesquisa sobre a música guarani.

Os estudos sobre música indígena nas Terras Baixas da América do Sul têm aumentado em número nos últimos anos - Menezes Bastos (2007), para o estado da arte. Os enfoques dos trabalhos são variados, alguns autores se esforçam na tradução das letras dos cantos, outros concentram sua atenção na performance, outros discutem os aspectos ontológicos, as relações entre humanos e não humanos, por exemplo, que perpassam estes universos (Lewy; Brabec de Mori; Garcia, 2015), entre outras abordagens. Alguns pesquisadores insistiram na importância de mergulhar no código musical, considerando sua plena semanticidade. Nas outras musicologias, não há nenhuma dúvida acerca da rentabilidade das análises musicológicas; no entanto, quando o assunto é a música indígena, nem sempre esta opinião foi unânime.

O próprio esforço de tradução dos cantos indígenas, por si só, já é uma análise musicológica, quando feita de forma rigorosa. As palavras sofrem transformações quando são musicadas. No decorrer do tempo, no caso das músicas indígenas, muitas vezes os cantores não têm a exegese do que estão cantando. Vou dar o exemplo dos cantos Guarani, com os quais trabalhei. Os Guarani Nandeva cantam muitas vogais, o que foi descrito por alguns pesquisadores, como cantos sem letras. Numa análise mais atenta, dos mesmos cantos executados em dias distintos, pude observar que os "as, es, is, e os" estão sempre no mesmo momento da melodia. Chase-Sardi (1992), pesquisador paraguaio, reuniu cinco xamãs e conseguiu algumas exegeses destes cantos. De acordo com minha análise, esses são cantos que foram se transformando e nos quais as vogais ficaram mais evidentes, mas há uma semântica ali, como há também nas músicas instrumentais, que "falam".

Não vou ser exaustiva na exploração dos autores que têm se dedicado ao desafio de analisar as músicas indígenas das Terras Baixas da América do Sul. Entre eles, podemos citar Anthony Seeger (2015), 
Jonathan Hill (1993), Acácio Piedade (2004), Maria Ignez Mello (2005), Rosangela Tugny (2009a; 2009b) e Ana Paula Lima Rodgers (2014), entre outros.

Darei especial destaque aqui a Rafael Menezes Bastos, por considerar um dos que mais tem "militado na causa". Menezes Bastos (2013) realizou um trabalho de fôlego ao analisar, musicalmente, o ritual da jaguatirica em sua integridade. Além disto, orientou e orienta diversas pesquisas que vão para a mesma direção.

O mergulho no código musical constitui, no caso dos povos desta região, um procedimento de respeito à importância que a linguagem musical tem nestes universos. As linguagens artísticas tem uma centralidade marcada nos mundos ameríndios, e levá-las a sério nas etnografias tem se mostrado uma porta de entrada privilegiada para a compreensão de suas ontologias.

A análise atenta do material musical pode ajudar a iluminar áreas da vida social, como as relações de gênero, por exemplo. Os trabalhos feitos com os Wauja (grupo Arauake do Xingu), por Piedade (2004) e Mello (2005), sobre os repertórios de flautas sagradas Kawoka e os cantos de mulheres yamurikuma, respectivamente, mudam a perspectiva sob a qual as questões de gênero vinham sendo analisadas na região. As mulheres são proibidas de ver os instrumentos Kawoka, porém elas devem ouvi-las. Ao estudar o repertório de yamurikuma, comparando com o dos instrumentos sagrados, Mello identificou que alguns dos motivos das melodias eram os mesmos. Isso já corroborava o que Mello já havia escutado de seus interlocutores, que yamurikuma era música de kawoka. Os homens também aprendem os cantos das flautas e trompetes com as mulheres. Cito aqui apenas um exemplo da contribuição que a dedicação à análise do código musical pode dar. Tal análise é um desafio, porque demanda muito tempo, e no percurso, o pesquisador não está seguro se vai conseguir fazer alguma conexão interpretativa.

Um dos desafios que se coloca é a questão da maneira de transcrever e a própria validade do uso das ferramentas desenvolvidas no mundo ocidental transpostos para o mundo ameríndio. Esse é um dos desafios que só será vencido com o mais antigo método de construção do conhecimento: tentativa e erro. Penso que a interlocução cada vez 
mais simétrica entre pesquisador e nativo e os nativos realizando suas pesquisas podem desenvolver outras ferramentas de análises da transcrição. O importante é colocar a musicalidade no centro da análise. Como fazer isto é o desafio, é o próprio trabalho. Precisamos estar abertos para criar, preferencialmente com a parceria dos indígenas, formas de colocar no papel os aspectos significativos da música. Em algumas situações, pode ser a melodia; em outras, o ritmo; em outras ainda, e este parece ser o caso de muitas musicalidades indígenas, o timbre. Continuo defendendo que a transcrição é importante para que nossos ouvidos consigam captar detalhes significantes. A maneira de fazê-la é uma construção constante. E essa é uma atividade que ajuda na formulação de perguntas, alertando para uma escuta mais cuidadosa. Não se trata de um fim em si mesmo e não é objetivo representar, congelar ou qualquer coisa parecida, é apenas uma ferramenta de análise.

\section{Jeroky - Revisitando Análises}

Vou narrar aqui como me coloquei este desafio, revisitando reflexões iniciadas durante a pesquisa de doutorado, iniciada em 1997, sobre a música e os caminhos guarani, dando a elas continuidade, e relacionando com a pesquisa que estou desenvolvendo atualmente. Quando iniciei as análises dos cantos, coloquei-me como desafio verificar as possibilidades de relacionar o material musical a esta capacidade de deslocamento espaço temporal.

No repertório que estudei, dos rituais cotidianos, os jeroky, identifiquei dois gêneros: um ligado à prece, que é individual, e outro denominado yvyra 'i $i$ ja, que é coletivo - para mais detalhes ver Montardo (2009). O termo Yvyra'íja significa o portador da vara de madeira pequena e é utilizado para se referir a várias situações, tais como, os ajudantes do xamã, os que estão em processo de iniciação e aprendizado no xamanismo, os seres espirituais que são auxiliares do xamã principal que é o Pa'i Kuara, ou Nhanderu. A expressão tem conotações guerreiras, a vara de madeira que porta é uma arma e este gênero musical é acompanhado por danças de treinamento de lutas. 
Um dos elementos que destaquei na análise apresentada em Montardo (2009) baseada nos cantos do casal de xamãs Leonardo e Vitória, residentes na Terra Indígena (TI) Piraju 'y, município de Paranhos MS. No jerokyha, "casa de dança", fica o altar, yvyra'i, composto de três madeiras perfiladas e unidas por duas madeiras deitadas e fios adornados com penas de pássaros. Na madeira do meio, há uma cruz feita de taquara adornada com penas de louro (Amazona sp.) (Figura 1).
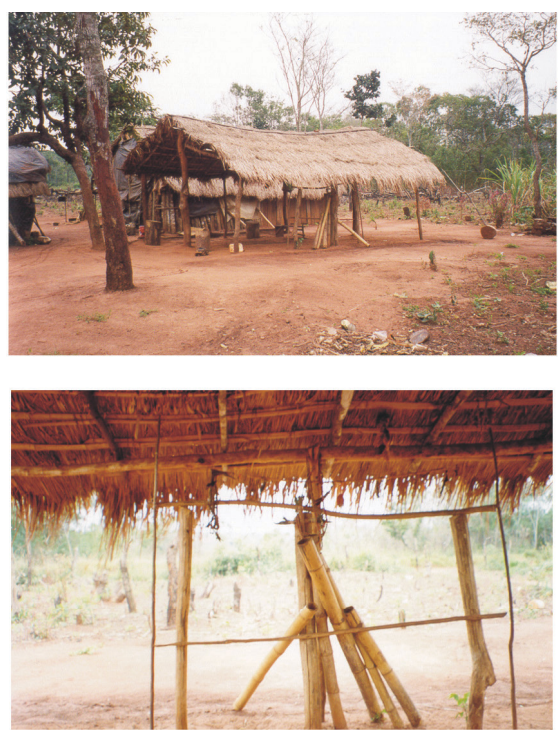

Microfone

Yvyra'i

\section{- Banco}

Figura 1: Esquema e fotos da casa de dança, jerokyha Fonte: Montardo (2009, p. 110)

Em uma introdução de cerca de um minuto e meio, o ñanderu toca o mbaraka (chocalho) em posição vertical, depois faz um recitativo da canção a ser executada. Após o recitativo, ele muda a posição da execução do mbaraka, tocando-o horizontalmente, marcando uma pulsação. Nesse momento, as mulheres começam a cantar e a tocar os takuapu (bastão de ritmo) de encontro a uma madeira, que fica no chão para esse fim (Figura 2), e alguns dos demais participantes começam a dançar. 


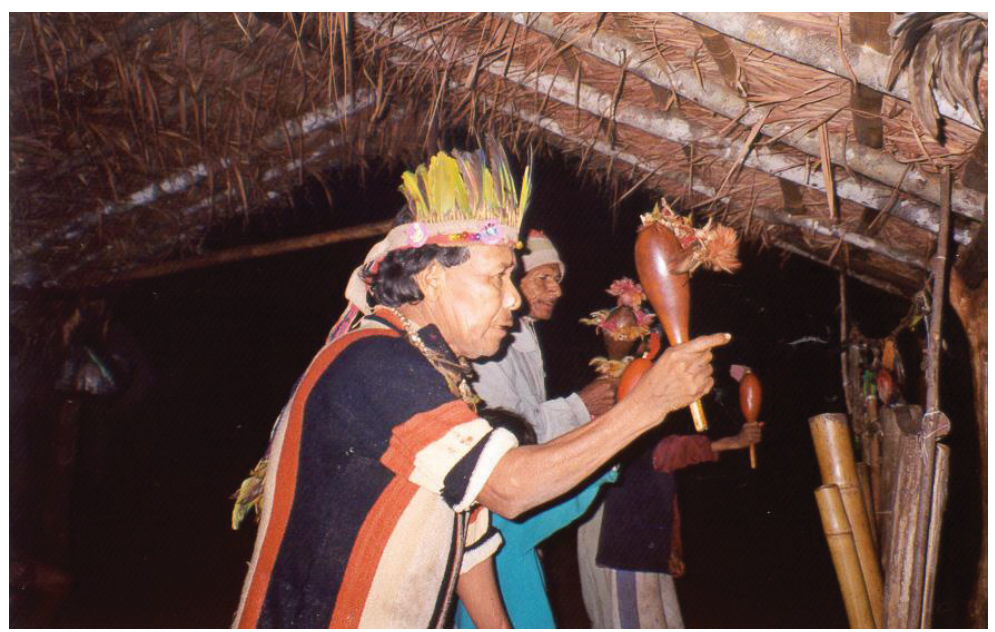

Foto 1: Leonardo Verá executando mbaraka na posição vertical Fonte: Montardo (2009, p. 111 )

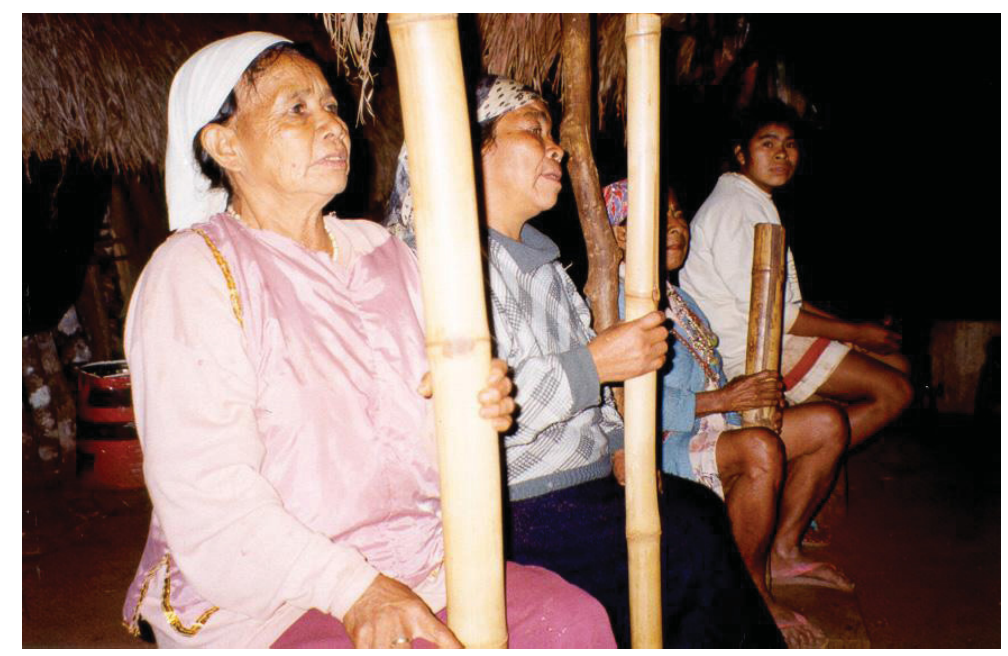

Foto 2: Mulheres executando takuapu

Fonte: Montardo (2009, p. 112)

Durante a pesquisa, a dança se impôs e outro desafio se colocou. Desenvolvi então uma transcrição das coreografias observadas. Em Montardo (2009), há um detalhamento dos movimentos corporais e das variações coreográficas registradas durante os oito meses que nos quais estive em campo. Selecionei aqui um dos movimentos que consegui relacionar ao material musical. 
É o momento no qual o condutor do ritual, yvyra'ija tenondé, o "principal", sinaliza com o mbaraka e começa a circular no interior da casa (Figura 2a), no sentido anti-horário, ojere (Figura 2b), no que é seguido por outros dançarinos e dançarinas. Quando há um número maior de participantes, formam-se círculos concêntricos. As mulheres giram de mãos dadas direcionadas numa diagonal entre o centro do círculo e a pessoa que está na sua frente, mantendo o mesmo movimento com os pés, um empurrando o outro.

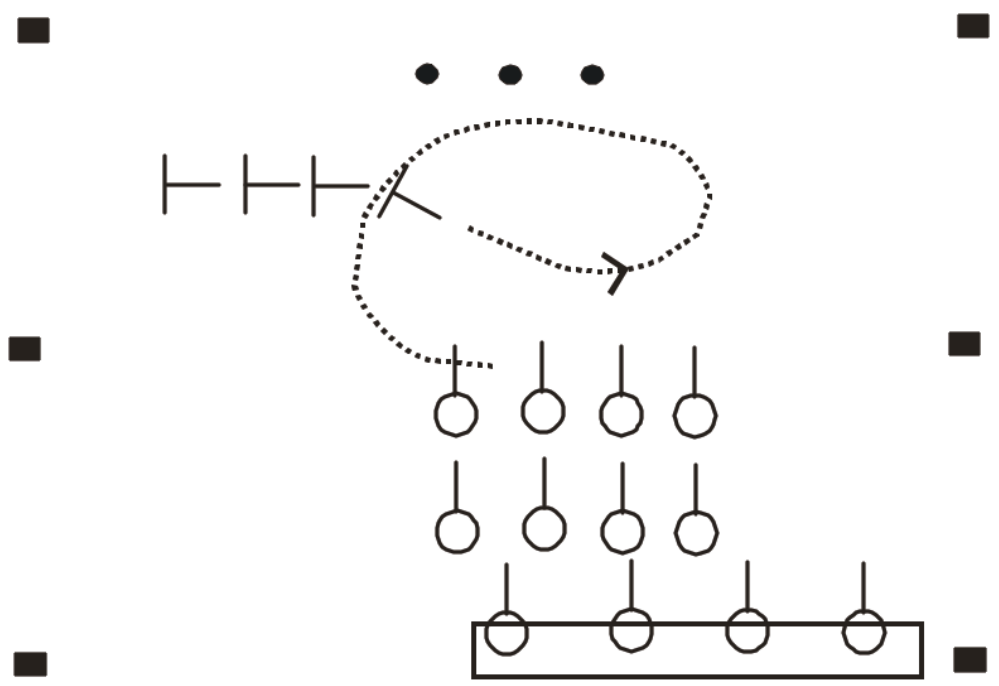

Figura 2a: Esquema do início do movimento ojere, o ojere e o ojevy

Fonte: Montardo (2009, p. 114)

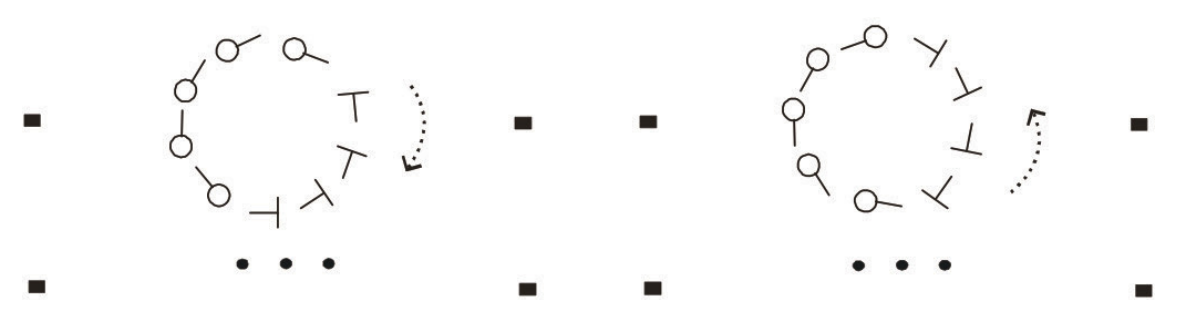

Figura 2b: Esquema do início do movimento ojere, o ojere e o ojevy Fonte: Montardo (2009, p. 114) 
Na hora em que o canto atinge o ponto mais agudo eles invertem o sentido do caminhar no círculo, ojevy (Figura 2b). Mudam a direção desse círculo cerca de quatro ou cinco vezes e retornam à posição inicial. Nas noites em que participei, as coreografias foram estas, acrescidas algumas vezes por umas duas ou três voltas em círculos maiores dadas ao redor do yvyra 'i (Figura 3). Ojere é o termo utilizado para falar do movimento do Sol. Os caminhos realizados durante os rituais estão relacionados com os movimentos do Sol, a luz que emana o herói criador.

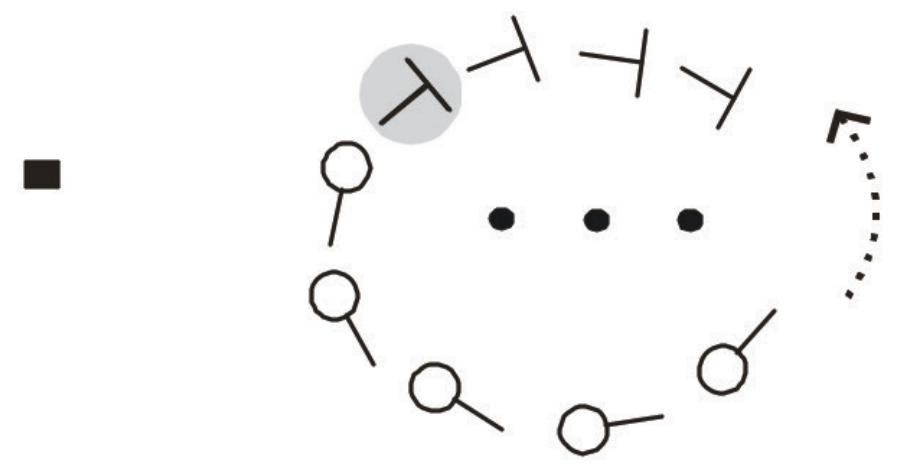

Figura 3: Movimentação em círculos ao redor do yvyra'i

Fonte: Montardo (2009, p. 115)

Há momentos, durante algumas canções, nos quais se realiza uma dança/luta, denominada yvyra'ija, na qual o yvyra'ija principal, o ajudante do xamã, tenta atingir um dançarino após o outro com o mbaraka. Ele caminha dando voltas pela casa e pelo pátio, com os joelhos bem flexionados, e todos os participantes em fila, atrás dele, como se ele estivesse abrindo caminho (Figura 4). Depois, no centro da casa, desafia os participantes com movimentos rápidos de ataque com o mbaraka, ao som dos cantores em coro: “he! he! he!" Durante esta dança os lutadores pulam com os dois pés juntos. O condutor do ritual passa o mbaraka por baixo dos seus pés e eles pulam, defensivamente. Uma das funções do yvyra'ija, como ajudante do xamã, é fazer esse treino que chamam oñemoitÿ. Ñemoichï está traduzido por Cadogan (1992, p. 127) como “[...] movimentos rápidos que os homens executam em uma dança na qual imitam uma dança dos Tupãs", Tupãs são espíritos auxiliares do herói criador. 


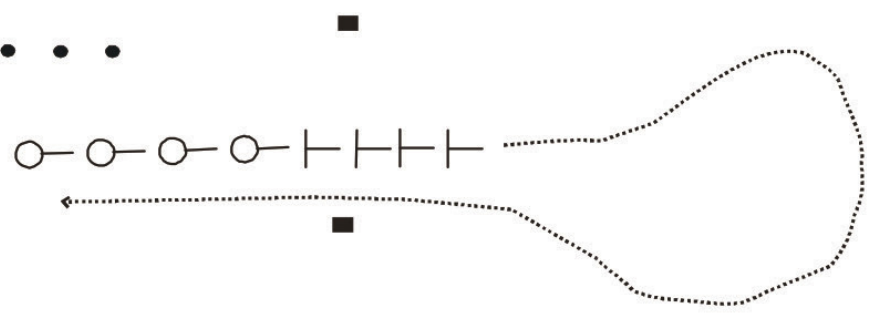

Figura 4: Movimentação do yvyra'ija

Fonte: Montardo (2009, p. 115)

Observei nas canções nhandevas um padrão morfológico a partir de tipos de motivos ou eixos motívicos. Ocorre um eixo no qual as frases começam num tom mais distante do centro tonal (mais agudo, diríamos, na teoria musical ocidental). Denominei esse eixo de A e de $\mathrm{Al}$, consecutivamente, variações, conforme apareceram. É como se essa frase A abrisse caminho, sendo o momento de maior adensamento sonoro do coro feminino. Na coreografia, esse é o momento em que se inverte o sentido do giro do círculo, tanto para o sentido anti-horário, ojere, como para o contrário, ojevy, e é bem marcado. Há depois uma frase, intermediária, na qual as notas da melodia brincam entre esse tom mais agudo, oscilando ao redor do centro tonal, a qual chamei de B. O eixo que enfatiza o centro tonal, denominei de C.

Na maioria das canções nhandevas analisadas, é possível verificar que há um crescendo no número de repetições do eixo $\mathrm{C}$ da canção, até atingir um número máximo de repetições. Em algumas canções chegaram a ser cerca de 50 repetições. No exemplo abaixo foram 12. A partir desse ápice, a performer passa a reduzir o número de repetições gradativamente, até voltar a mesma duração do início. Durante as execuções, no entanto, os motivos iniciais, a parte mais aguda do canto, são sempre recuperados em sua forma e em seu tamanho originais, são invariantes (Figura 5). 


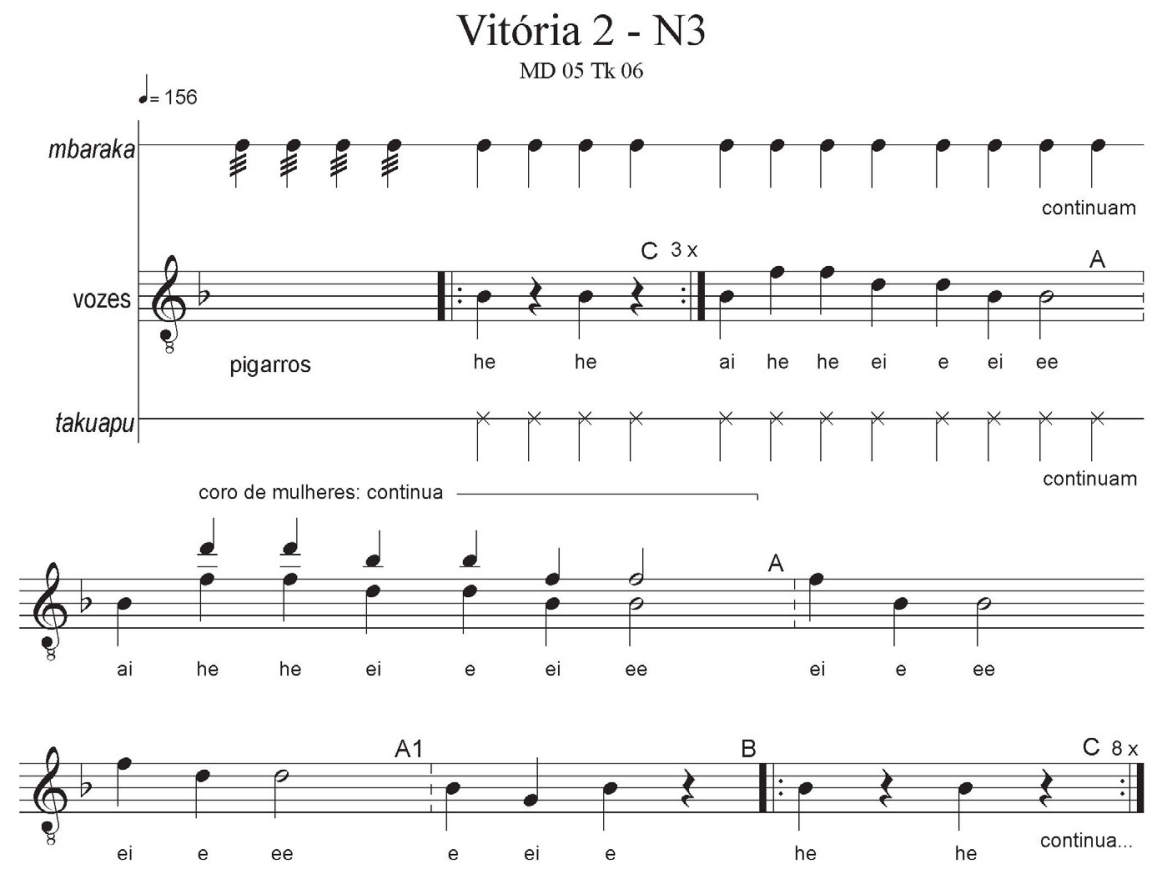

Figura 5: Yvyra'ija Nhandeva

Fonte: Montardo (2009, p. 123)

Tabela 1: "Estrutura da canção"

\begin{tabular}{|c|c|c|c|c|}
\hline 3C & A & A & A1 & B \\
\hline 8C & A & A & A1 & B \\
\hline 9C & A & A & A1 & B \\
\hline 12C & A & A & A1 & B \\
\hline 7C & A & A & A1 & B \\
\hline 9C & A & A & A1 & B \\
\hline 5C & & & & \\
\hline
\end{tabular}

Fonte: Montardo (2009, p. 123)

A canção acima, entoada por Vitória Vera, na Área Indígena Piraju'y, Paranhos (MS), é uma das definidas como sendo yvyra 'ija. O refrão "he! he! he!" é uma das características. Nessa parte é que se intensificam as lutas, o ritmo é acelerado e as coreografias se expandem para fora da casa. Minha sugestão é que há uma relação entre esta extensão no tempo e ampliação do espaço por onde os dançarinos circulam na ação de percorrer caminhos. 
A interlocução com Dona Odúlia Mendes, yvyra ‘ija Kaiowá, que residia na época da pesquisa, na Área Indígena Amambai, Amambai (MS), foi fundamental também para a compreensão desta relação entre a música e a dança e o percorrer de caminhos no ritual jeroky. Dona Odúlia, viveu durante sua iniciação entre os nhandeva, na Área Indígena Porto Lindo, Japorã (MS) e tinha no seu repertório algumas canções que creditava serem deste outro subgrupo guarani. Ela afirmava que a incorporação desse repertório a ajudava a aumentar a força do seu trabalho. Uma das canções que Dona Odúlia me apresentou como sendo guarani nhandeva foi denominada por ela de Ka'agui poti rehegua. A tradução literal do nome dessa canção é ka'a - mato, gui - do, poti - flores, rehe - por intermédio de e gua - de/procedência, canção das flores das copas das árvores. Daniel, ajudante ritual de Dona Odúlia, explicou que, com este canto, eles vão até a altura da copa das árvores. Ele usou o seguinte exemplo: "se estivermos de avião, o que vemos do mato são as copas das árvores". O nome do canto refere-se a elas. Daniel traduziu-o como "no meio das flores, do mato". Com esta reza, segundo ele, se vai até esta altura e, para continuar, tem-se que pegar outra.

Ele continuou dizendo que, se a xamã quiser seguir adiante e ir mais para o fundo, mais para lá, tem que passar para uma outra reza, que é de kaiowá mesmo.

Dasmela cantará, cantará, chega, pega outro e vai indo, vai indo e vai até amanhecer assim. E ao voltar, ela foi para lá, vamos supor que até vamos supor se ela quiser voltar, tem que vir de lá, vamos supor que até no fim da reserva, ela tem que cantar de novo o que antes ela cantou, quando subiu, para ela poder descer de novo. (Daniel Vasquez)

Daniel comentou então que os participantes do ritual que se cansam e param no caminho têm que ser recolhidos, e por isso a necessidade de que a xamã percorra o mesmo caminho de volta. Se isto não acontecer, a pessoa que ficou lá adoecerá.

Menciono esse exemplo para trazer a baila que os caminhos percorridos pelos Guarani no jeroky, são tanto horizontais, como verticais. Como mencionado, eles levam a deslocamentos como os que 
se fazem até as cidades vizinhas da terra indígena, como o exemplo citado Amambai, mas são feitos em movimentos de parábolas, com movimentos ascendentes e descendentes. Recorro a um dos desenhos de Silvano Flores, filho de Dona Odúlia, para demonstrar estes caminhos percorrido, no caso do desenho, para as aldeias divinas, que ficam nos pontos cardeais - para maiores detalhes, ver Montardo (2009) (Figura 6).

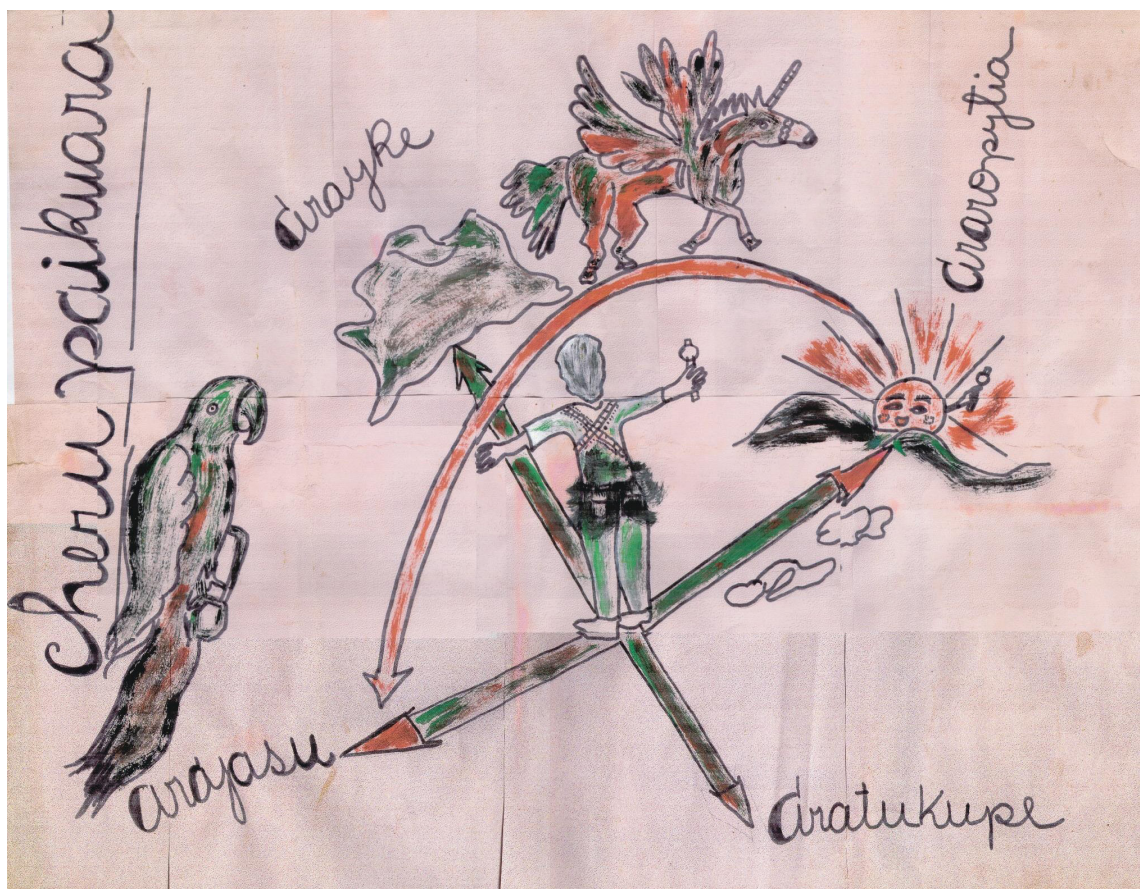

Figura 6: Desenho de Silvano Flores mostrando os deslocamentos dos seres de um ponto cardeal a outro

Fonte: Montardo (2009, p. 201)

Mostro esse material tal como apresentei há cerca de 20 anos na tese de doutorado. Refletindo sobre ele, não me arrependo do investimento feito, e considero que foi importante, principalmente como meio para aguçar e refinar a escuta e a observação dos movimentos corporais. Tenho clareza de que a maioria dos insights foi proporcionado pela observação das coreografias, dos movimentos das danças, dos desenhos, das exegeses. Porém, não teria chegado a tais interpretações 
se não tivesse tido o trabalho de fazer as transcrições tanto da música como dos movimentos da dança. Como mencionei no início, na minha opinião, o desafio teórico-metodológico nos estudos sobre estas musicalidades e corporalidades vai sendo vencido a cada trabalho, com o detalhamento de repertórios de grupos, a respeito dos quais nunca nenhum pesquisador se debruçou.

Finalizo este artigo reforçando a ideia de estamos, no que se refere as etnografias sonoras, em uma caminhada na qual cada passo dado, é significativo. E que as musicalidades todas devem ser objetos de nossa atenção. Os Guarani Nhandeva e Kaiowá enfrentam uma situação muito difícil, foram expulsos de seus territórios tradicionais nos últimas décadas, pelas frentes expansionistas do agronegócio. Nas lutas pelas retomadas de seus tekoha, os cantos e as danças cerimoniais são armas importantes, às quais se somaram os rappers ${ }^{1}$. Assim, afinar a escuta e as ferramentas teórico-metodológicas para tratar dos sons e dos movimentos corporais, nos exige uma abertura para observação do que para eles é importante, o que lhes garante a força e vitalidade para seguir.

\section{Notas}

1 O tema do caminho está presente na obra dos Bro MC, jovens kaiowá que estão, há alguns anos, fazendo rap. Uma das canções que tematiza o caminho está disponível no YouTube no endereço: <https://www.youtube. com/watch?v=oLbhGYfDmQg $>$, publicado em 28 de setembro de 2010 e se chama Eju orendive.

\section{Referências}

CADOGAN, Léon. Diccionario Mbya-Guarani Castellano. Asunción: Fundacion "Leon Cadogan" Ceaduc Cepac, 1992. (Biblioteca Paraguaya de Antropologia, v. XVII).

CESARINO, Pedro de Niemeyer. Oniska: Poética do Xamanismo na Amazônia, São Paulo: Perspectiva/Fapesp, 2011.

CHASE-SARDI, Miguel. "El Precio de la Sangre" - Tugrecio drepy. Estudio de la Cultura y el Control Social entre los Avá-Guaraní. Assunção: Centro de Estudios Antropológicos de la Universidad Católica (CEADUC), 1992. 
FELD, Steven. Sound and Sentiment: Birds, Weeping, Poetics, and Song in Kaluli Expression. Durham; London: Duke University Press, 2012.

GLOWCZEWSKI, Barbara. La Loi du rêve: approche topologique de l'organisation sociale et des cosmologies des Aborigènes australiens. Lille: ANRT, 1989.

HILL, Jonathan. Keepers of the Sacred Chants: the Poetics of Ritual Power in an Amazonian Society. Univ. of Arizona Press. 1993.

LEWI, Matthias; BRABEC DE MORI, Bernd; GARCIA, Miguel. "Introdução". In: BRABEC DE MORI, Bernd; LEWY, Matthias, GARCIA, Miguel A (Ed.). Estudios Indiana 8: Sudamérica y sus mundos audibles. Berlin: Ibero-Amerikanisches Institut/Gebr; Mann Verlag, 2015.

PIEDADE, Acácio T. C. O canto do kawoká: Música, Cosmologia e Filosofia entre os Wauja do Alto Xingu. 2004. 254f. Tese (Doutorado) Universidade Federal de Catarina, Florianópolis, 2004.

MELLO, Maria I. C. Iamurikuma: Música, Mito e Ritual entre os Wauja do Alto Xingu. 2005. p. 335. Tese (Doutorado) - Universidade federal de Santa Catarina, Florianópolis, 2005.

MENEZES BATOS, Rafael J. A festa da jaguatirica: uma partitura crítico-interpretativa. Florianópolis: Editora da UFSC, 2013.

. Música nas sociedades indígenas das terras baixas da América do Sul: estado da arte. Mana, Rio de Janeiro, v. 13, n. 2, p. 293-316, outubro, 2007. Disponível em: <http:/www.scielo.br/scielo.php?script=sci arttext\&pid $=$ S0104-93132007000200001 $8 \operatorname{lng}=\mathrm{en} \delta \mathrm{nrm}=\mathrm{iso}>$. Acesso em: 27 jul. 2017.

MONTARDO, Deise Lucy Oliveira. Através do Mbaraka: música, dança e xamanismo guarani. São Paulo: Edusp. 2009.

RODGERS, Ana P. L. O Ferro e as Flautas: regimes de captura e perecibilidade no Iyaõkwa Enawene Nawe. 2014. 463 p. Tese ( Doutorado) - Universidade Federal do Rio de Janeiro, Rio de Janeiro, 2014.

ROSEMAN, Marina. Healing Sounds from the Malaysian Rainforest Temiar Music and Medicine. Califng So: University of California Press, 1993.

SEEGER, Anthony. Os índios e nós: estudos sobre sociedades tribais brasileiras. Rio de Janeiro: Campus, 1980.

. Por que cantam os Kĩsêdjê. Trad. Guilherme Werlang. São Paulo: Cosac Naify. 2015. 
TOWNSLEY, Graham. Song Paths The Ways and Means of Yaminahua Shamanic Knowledge. L'Homme, La remontée de l'Amazone, tome 33, n. 126-128. p. 449-468, 1993.

TUGNY, Rosângela Pereira et al. Y.mĩyxop Xũnĩm y.g Kutex xi .gtux xi hemex y.g Kutex/Cantos e histórias do morcego-espíto e do hemex. Rio de Janeiro: Azougue, 2009a.

. M.gm.ka y.g Kutex xi .gtux/Cantos e Histórias do gavião espíto. Rio de Janeiro: Azougue, 2009b.

TURINO, Tomaz. Moving Away from Silence: music of the peruvian altiplano and the experience of urban migration. Chicago: The University of Chicago Press. 1993.

Recebido em 15/01/2018

Aceito em 30/04/2018 